\title{
FRANCIAORSZÁG ÉS A FRANCIÁK EGY XV. SZÁZADI BIZÁNCI TÖRTÉNETÍRÓ SZEMSZÖGÉBÖL*
}

\section{Szabics Imre emlékére}

„Az utolsó athéni történetíró”, Laonikos Chalkokondylés enciklopédikus kitekintésü műve, az Apodeixis, világtörténeti jellegénél fogva jóval több, mint a bizánci birodalom hanyatlását és az oszmán törökök felemelkedését bemutató összegzés. A valamikor a XV. század utolsó harmadában keletkezett, tíz könyvből álló remekművében a szerző a fó téma mellett részletes tájékoztatást nyújt jóformán a lakott világ valamennyi részéről, ami az 1298-tól 1463-ig terjedő időszakot illeti. Bár szakirodalmi közhely, hogy Chalkokondylés legfőbb mintája ebből a szempontból, vagyis a világtörténeti szemlélet alkalmazásából is Hérodotos volt - Thukydidés hatásával bizonyos formai tekintetben szintén számolnunk kell ${ }^{1}$-, egyetértünk azzal a kijelentéssel, hogy az első olvasásra is szembetűnő tartalmi és formai párhuzamok azonosítása mellett érdemes lenne az imitatio mélyebb rétegeibe is bepillantást nyernünk. ${ }^{2}$ Nem feltétlenül az alapkoncepció átvételére (görögség contra barbár [perzsa], illetve „pogány” [török] nép), az egyes történetek, földrajzi leírások, szereplők aligha véletlenszerü hasonlóságára vagy éppen szövegszerű kölcsönzésekre gondolunk tehát, hanem inkább általános szerkesztésbeli, s ezzel összefüggésben világnézeti sajátosságokra, melyek Chalkokondylést szorosabban kötik antik előképéhez, mint saját kortársai többségéhez. Ennek szemléltetésére kiváló eszköz a mindkét szerzőnél nagy számban előforduló néprajzi kitérők elemzése, annál is inkább, mert a Chalkokondylés-filológia kortárs képviselői is megkülönböztetett figyelmet szentelnek ezeknek a leírásoknak (leginkább a saját népükre vonatkozóan), melynek nyomán időnként - véleményünk szerint - helytelen képet alkotnak a szerzőről és művéről. ${ }^{3}$

* A tanulmány az NKFIH NN 124539 jelzetű pályázat támogatásával készült.

${ }^{1}$ Vö. F. Rödel: Zur Sprache des Laonikos Chalkondyles und des Kritobulos aus Imbros. Programm des K. humanistischen Gymnasiums Ingolstadt für das Schuljahr 1904/1905. München 1905.

${ }^{2}$ A. Markopoulos: Das Bild der Anderen bei Laonikos Chalkokondyles und das Vorbild Herodot. JÖB 50 (2000) 205-216, kül. 210: „Hier sei vermerkt, daß bislang eher an der Oberfläche bleibende Positionen vertreten wurden, die in der Regel der Ansicht zuneigen, daß Chalkokondyles, da er ja viele fremde Völker beschreiben wollte, fast natürlich auf Herodot als historische Vorlage zurückgreifen mußte. Ich glaube jedoch, daß diese allzu vereinfachende Position heute keine ernsthaftere Unterstützung mehr beanspruchen darf; im Übrigen bedeutet sie indirekt auch eine Unterbewertung des Chalkokondyles selbst als Historiker."

${ }^{3}$ Jellemző, hogy a már jó néhány évtizede közölt tematikus Chalkokondylés-válogatás is a kitérők szövegéből válogatott: F. Grabler: Aus dem Geschichtswerk des Laonikos Chalkokondyles. In: Europa im XV. Jahrhundert von Byzantinern gesehen. Hg. E. von Ivánka. Graz - Wien - Köln 1954. 11-97. Vö. például: $H$. Ditten: Spanien und die Spanier im Spiegel der Geschichtsschreibung des byzantinischen Historikers Laonikos Chalkokondyles. Helikon 3 (1963) 170-195; H. Ditten: Bemerkungen zu Laonikos Chalkokondyles' Nach- 
Kiindulópontként mindjárt meg is fogalmazhatunk két, mind Hérodotos, mind Chalkokondylés etnográfiai exkurzusaira egyaránt érvényes általános törvényszerűséget: (1) Chalkokondylés (és Hérodotos) mindig azon a ponton illeszt be a történeti elbeszélésbe egy-egy néprajzi kitérőt, ahol a szóban forgó nép története valamilyen (általában kronológiai) szempontból összekapcsolódik a fő narratívával; (2) Chalkokondylés (és Hérodotos) etnográfiai exkurzusai mindig azonos, kötelező elemekből épülnek fel (a földrajzi környezet leírása, az államforma és a közigazgatási rendszer bemutatása, az adott népre jellemző tulajdonságok, szokások felsorolása, történeti áttekintés, valamint az egyéb természetföldrajzi adottságok ismertetése). A kitérők funkciója kettős: egyrészt ellátják az olvasót a történet pontos megértéséhez nélkülözhetetlennek tekintett ismeretekkel, másrészt az elbeszélés átmeneti megszakításával késleltetik a bemutatni kívánt történeti esemény (ütközet, hadjárat stb.) végkifejletének kibontakozását, ezzel is növelve a várakozást.

Mivel terjedelmi okokból mindenképpen válogatnunk kell az exkurzusok közül, az alkalomra való tekintettel most a franciákkal és Franciaországgal kapcsolatos Chalkokondylés-szemelvényeket kívánjuk röviden bemutatni azzal a szándékkal, hogy árnyaljunk néhány, a köztudatban megkérdőjelezhetetlen alapvetésként rögzült állítást. ${ }^{4}$ Utóbbiak kivétel nélkül megjelennek a néhány éve elhunyt jeles toulouse-i történész, Alain Ducellier tárgyunkhoz kapcsolódó tanulmányaiban. ${ }^{5}$ Mielőtt áttérnénk a konkrét szövegrészletekre, érdemes legalább felsorolásjelleggel ismertetnünk a szóban forgó (általunk vitatott) téziseket. Ducellier szerint a bizánciak földrajzi kérdésekben tá-

richten über die Länder und Völker an den europäischen Küsten des Schwarzen Meeres (15. Jahrhundert u. Z.). Klio 43-45 (1965) 185-246; H. Ditten: Der Russland-Exkurs des Laonikos Chalkokondyles interpretiert und mit Erläuterungen versehen. Berlin 1968; M. Morfakidis: La península Ibérica en la obra de Calcocondilas. Erytheia 6 (1985) 69-82; V. Angelov: Laonikos Chalkokondyles on Bulgaria and the Bulgarian History. Bulgaria Mediaevalis 3 (2012) 247-253.

${ }^{4}$ A jelen tanulmány alapjául szolgáló előadás eredetileg a Byzanz und das Abendland / Byzance et l'Occident VII címmel megrendezett nemzetközi konferencia Szabics Imre emlékére rendezett ülésszakán (Hommage à Imre Szabics) hangzott el 2019. november 26-án. Az Apodeixis francia vonatkozásaihoz tartozik, hogy az első nyomtatásban megjelent változatot (a latin fordítást) a latinból készült francia fordítás követte 1577-ben, és csak harmadjára közölték eredeti nyelvén, azaz görögül a művet. A francia fordító, a híres-hírhedt diplomata és kalandor Blaise de Vigenère volt, aki részben az európai humanista értelmiség törökök iránti éledező kíváncsiságát kívánta csillapítani munkájával, de közben legalább ennyire igyekezett megfelelni támogatóinak, elsősorban Louis de Gonzague-nak, Nevers hercegének, a későbbi III. Henrik tanácsadójának, amennyiben a pogányok ellen vívott harc célzatosan eltorzított bemutatásával próbált valamiféle ideológiai párhuzamot szolgáltatni a hugenották elleni vallásháborúhoz. További francia kapcsolata a szöveghagyománynak, hogy a Chalkokondylés-kiadók között tartjuk számon Charles Annibal Fabrot jogtudóst is, aki 1650-ben tette közzé a görög szöveget az ún. párizsi corpusban.

${ }^{5}$ A szempontunkból ezúttal leginkább releváns tanulmány: A. Ducellier: La France et les Îles Britanniques vues par un byzantin du XV siècle: Laonikos Chalkondylis. In: Économies et sociétés au Moyen Âge: Mélanges offerts à Edouard Perroy. Paris 1973. 439-445. Vö. továbbá A. Ducellier: La péninsule ibérique d'après Laonikos Chalkondylis, chroniqueur byzantin du XVe siècle. Norba: Revista de historia 5 (1984) 163-177; A. Ducellier: L’Europe occidentale vue par les historiens grecs des XIV ème et XV ème siècles. Byzantinische Forschungen 22 (1996) 119-159. 
jékozatlanok, nem érdeklődnek más népek iránt, a világ rajtuk kívül eső részére pedig valamiféle felsőbbségtudattal tekintenek. ${ }^{6} \mathrm{Ha}$ ennek ellenére mégis megnyilvánulnak a fenti témák valamelyikében, beszámolóik csak a közvetlen szomszédaikra vonatkozóan tekinthetők hitelt érdemlőnek, a távolabbi népeket illetően viszont nem. ${ }^{7}$ Chalkokondylés földrajzi leírásai, az egyes népekről adott beszámolói meghaladják ugyan az átlagos színvonalat, de a franciákról közölt tudósítása elfogult, torz és franciaellenes szemléletet tükröz. ${ }^{8}$ A részrehajlás oka a bizánciak gyülölete a Konstantinápolyt elfoglaló frankok és általában a „latinok” iránt. ${ }^{9}$

Az utóbbi kijelentés cáfolatához önmagában elegendő már az is, ha a Chalkokondylés-életrajz jóformán egyetlen biztos pontjára hivatkozunk, nevezetesen arra a körülményre, hogy a szerző Geórgios Gemistos Pléthón tanítványa volt. ${ }^{10}$ Mindez ugyanis azt jelenti - s ez egyben a consensus philologorum is -, hogy Chalkokondylés mesteréhez hasonlóan szintén nem tekintette magát „görögül beszélő, ortodox rómainak” (ahogy a „bizánci polgár” klasszikus meghatározása hangzik): valószínűleg ő sem gyakorolta a keresztény hitet, hanem maga is "platonista újpogány” volt, mint Pléthón. ${ }^{11}$ Ebből adódóan idegenek tőle azok a hitviták, melyek nyomán bizánci-nyugati, illetve keresztény-pogány törésvonalakról beszélhetünk. Másokhoz - legyen szó akár egy népről, akár egy személyről - soha nem vallási-teológiai alapállásból közelít, s éppen ennek köszönhető, hogy művének még az iszlámot bemutató részei is szokatlanul tárgyilagosak, nélkülöznek mindenféle értékítéletet. Egyenesen következik mindebből, hogy Chalkokondylésre nem jellemző a bizánciak összességének tulajdonított nyugatellenesség („inkább a szultán turbánja, mint a pápa tiarája”), s végképp nem látjuk nyomát annak, hogy bármiféle gyülöletet táplálna a nyugati keresztény népek (frankok, latinok) iránt Konstantinápoly 1204-es elfoglalása miatt. Ami az utóbbit illeti, személyes emléke nem

${ }^{6}$ Vö. Ducellier: i. m. 1984 (5. jegyz.) 163: „...cette ignorance byzantine des réalités géographiques provient sans aucun doute de ce »complexe de supériorité« qui, à notre avis, caractérise l'empire grec médiéval: l'étranger ne vaut d'être connu que dans la mesure où il met en cause l'histoire même de Byzance, considérée a priori comme devant l'incorporer un jour dans le cadre d'un grand empire chrétien universel."

${ }^{7}$ Vö. Ducellier: i. m. 1984 (5. jegyz.) 163: „On comprendra dès lors que les renseignements donnés par les auteurs byzantins sur les nations étrangères peuvent être excellents quand il s'agit de voisins immédiats (pays balkaniques, Empire turc, républiques italiennes), mais qu'ils sont à peu près inexistants ou légendaires quand il s'agit de régions avec lesquelles Byzance n'a que peu ou pas de relations."

${ }^{8}$ Vö. Ducellier: i. m. 1973 (5. jegyz.) 442: „le caractère des Français est vu d'une manière très noire”; 445: „il apparaît évident que les renseignements donnés par notre auteur sur l'Europe occidentale proviennent d'une source nettement anti française".

${ }^{9}$ Vö. Ducellier: i. m. 1973 (5. jegyz.) 445: „...les Francs sont non seulement des envahisseurs qui n'ont pas craint, en 1204, de diriger une croisade contre des Chrétiens, mais surtout les porteurs par excellence de cette »religion latine «"

${ }^{10}$ Pléthónhoz lásd: F. Masai: Pléthon et le platonisme de Mistra. Paris 1956; C. M. Woodhouse: Gemistos Plethon: The Last of the Hellenes. Oxford 1986; N. Siniossoglou: Radical Platonism in Byzantium: Illumination and Utopia in Gemistos Plethon. Cambridge 2011.

${ }^{11}$ A. Kaldellis: A New Herodotus. Laonikos Chalkokondyles on the Ottoman Empire, the Fall of Byzantium, and the Emergence of the West. Dumbarton Oaks 2014. 102: „Plethon was also a Platonic neopagan who rejected Christianity". 
is lehet, de a család általunk ismert történetében ugyancsak nincs olyan elözmény, ami esetleg indokolhatna efféle ellenérzést. Ugyanakkor a görög identitás, a görög kultúra és nyelv megőrzése rendkívül fontos volt Chalkokondylés számára. ${ }^{12}$ De saját görögségének tudata sem akadályozta abban, hogy példaképéhez, Hérodotoshoz hasonlóan akkor is tisztelettel és megértéssel közelítsen a tárgyához, ha az éppen nem görög. Chalkokondylés maga is következetesen és hitelesen tudta képviselni azt a szemléletet, hogy a világot szenvedélymentesen, mindenféle elfogultság és elöítélet nélkül kell ábrázolnia. ${ }^{13}$

Chalkokondylés az Apodeixis második könyvének közepén (II, 30-37), II. Manuél Palaiologos császár 1399-es sikertelen nyugat-európai körutazásának leírása kapcsán kerít sort Franciaország bemutatására, vagyis a „kelta-exkurzusra”. Az anyagi támogatásért és katonai segítségért hasztalanul kilincselő uralkodó ekkor érkezik meg francia uralkodótársához, ahogy Chalkokondylés írja (II, 29): „Miután [Manuél] megérkezett a francia királyhoz, könyörgött neki, ne engedje, hogy a görögök fővárosát pogányok fenyegessék, hiszen a város a francia királyi családhoz is igen közel áll. Mire rájött, hogy a király megháborodott, és a fourak őrizet alatt tartják, hogy kikezeljék a betegségét, már elég hosszú időt eltöltött ott." ${ }^{14}$ Tehát ezúttal ez a konkrét történeti esemény, ez a jelenet, az őrült VI. Károllyal (1380-1422) történt kiábrándító találkozás szolgáltatta az alapot a kitérő beillesztésére, a franciák bemutatására.

A kitérő több részből áll: a 30. fejezetben a terület földrajzi fekvéséről olvashatunk, amit a 31. fejezetben az egyes tartományok bemutatása egészít ki (itt a szöveg romlott). Ezt követi Nagy Károlynak a mórok ellen vívott háborúiról szóló szakasz (32-33. fejezet), majd a 34. fejezetben a francia nép általános jellemzése. A kitérőt a százéves háború néhány kiragadott eseményének leírása zárja: Calais elfoglalása (35. fejezet), Poitiers (36. fejezet), Agincourt/Azincourt, valamint Jeanne D’Arc feltünése (37. fejezet), a következőkben pedig már Anglia leírásával folytatódik a szöveg.

Ahogy fentebb már említettük, Chalkokondylés életére vonatkozó adatok alig-alig állnak rendelkezésünkre, az utolsó érdemi forrásunk még a mystrai udvarban élő tehetséges fiatalemberként említi. ${ }^{15}$ Nem tudhatjuk, mennyivel élte túl Konstantinápoly

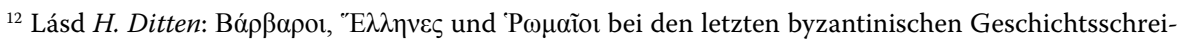
ber. In: Actes du XII ${ }^{e}$ Congrès International d'Études Byzantines II. Ochride 10-16 septembre 1961. Beograd 1964, 273-299.

${ }^{13}$ Kaldellis: i. m. (11. jegyz.) 101: „What Laonikos found in Herodotos was a non-Christian way of viewing cultural difference."

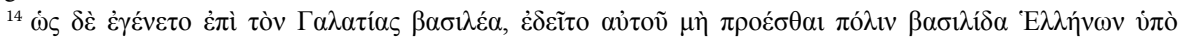

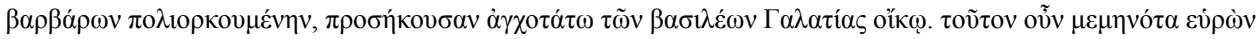

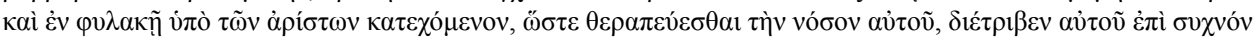

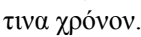

${ }^{15} \mathrm{Az}$ anconai Kyriacus szóban forgó naplóbejegyzése 1447 júliusából származik: Kyriacus of Ancona: Later Travels. Edited and translated by E. D. Bodnar (with C. Foss). Cambridge MA 2003. 298-303. 
elestét, ${ }^{16}$ mint ahogy azt is csak találgathatjuk, hol töltötte (ha egyáltalán megérte) öregkorát. ${ }^{17}$ Így aztán azt sem vehetjük biztosra, hogy voltak-e egyáltalán saját, autopsián alapuló tapasztalatai Franciaországról, vagy akár általában Nyugat-Európáról. Ha utóbbit illetően nem is, de előbbivel, Franciaországgal kapcsolatban az exkurzusokban közölt adatok szinte biztosan közvetett forrásból származtak, elsősorban hallomásból szerzett információkon, másodsorban pedig olvasmányélményeken alapulhattak.

Ennek ellenére, ami az exkurzus földrajzi adatait illeti, eltekintve attól a körülménytől, hogy a szerző és olvasói többsége számára valószínűleg nem sokat mondó földrajzi terminusok, városnevek helyenként archaizáló formában szerepelnek és a hagyományozódás során tovább deformálódtak, maga a beszámoló kirívó pontatlanságot nem tartalmaz. A közölt adatok, az országhatárok megnevezése, az ország nagyságának arányai, a városok és tartományok leírása megfelelnek a valóságnak. A terjedelemnek megfelelően elnagyolt, de hasonlóképpen pontos a feudális társadalmi rend bemutatása, Flandria jelentőségének érzékeltetése, valamint a tengeri kereskedelem fontosságára utaló megjegyzések. A Ducellier részéről általában nehezményezett földrajzi pontatlanságoknak magunk nem találjuk konkrét nyomát, sőt megkockáztatjuk, hogy a leírás semmivel nem megbízhatatlanabb, mint Hérodotos akármelyik hasonló jellegű kitérője, s nem indokolt, hogy ez alapján általános elmarasztaló ítéletet fogalmazzunk meg akár Chalkokondylés, akár a bizánciak földrajzi érdeklődését illetően.

Még meghökkentőbb, hogy a következő két fejezetnek a frank-arab összecsapásokról szóló részletes beszámolója nagyjából szintén egybevág az általunk ismert történeti tényekkel. Ráadásul itt még a szöveg is olvasmányosabb a megszokottnál: mintha a Roland-ének valamelyik oldalhajtásának prózai összegzését olvasnánk. A „líbiaiak” ( $\Lambda$ ißuعৎ) európai betörése, fokozatos terjeszkedése, majd visszaszorulása Granadába a görög historiográfiai gyakorlatnak megfelelő, de végeredményben hiteles bemutatása az eseményeknek. Arról nem is beszélve, hogy ebben a szakaszban expressis verbis a franciák hősies viselkedése a téma („úgy tartják, hogy a francia ősi nép, és hősies viselkedést tanúsított az észak-afrikai barbárokkal szemben”), ${ }^{18}$ szó nincs semmiféle tendenciózu-

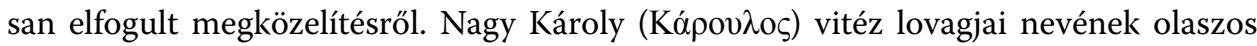

${ }^{16}$ A mű Trapezunt elfoglalásáról (1461) szóló részei már valószínűleg más szerzőtől származó betoldások. Vö. V. Grecu: Zu den Interpolationen im Geschichtswerke des Laonikos Chalkokondyles. Bulletin de la séction historique de l'Académie Roumaine 27 (1946) 92-94; A. Kaldellis: The Interpolations in the Histories of Laonikos Chalkokondyles. GRBS 52 (2012) 259-283.

${ }^{17}$ A három eddig felvetett lehetőség: a) Chalkokondylés a török terjeszkedés miatt a peloponnésosi Mistrából Krétára költözött, és ott élt haláláig (vö. J. Darkó: Zum Leben des Laonikos Chalkondyles. BZ 24 [1924] 29-39); Darkó J.: Michael Apostolios levelei Laonikoshoz. In: Emlékkönyv Csengery János születésének hetvenedik évfordulójára. Szeged 1926. 108-112; E. Darkó: Neue Beiträge zur Biographie des Laonikos Chalkokandyles. BZ 27 [1927] 276-285); b) Chalkokondylés keleten maradt, és a konstantinápolyi török udvarban írta meg müvét (Kaldellis: i. m. [11. jegyz.] 1-15 és 243-248); c) nem zárható ki, hogy Chalkokondylés Nyugat-Európába került ( $A$. Akışık: Self and Other in the Renaissance: Laonikos Chalkokondyles and the Late Byzantine Intellectuals. PhD dissertation. Harvard University 2013). $\lambda \alpha \mu \pi \rho \alpha ́$.

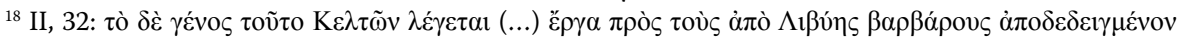




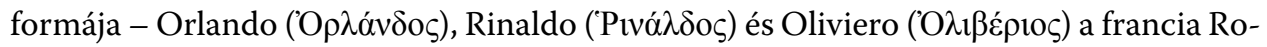
land, Renaud és Olivier helyett - mindenesetre itáliai forrásra enged következtetni.

A kitérő leghosszabb része, a százéves háborúról szóló beszámoló ugyancsak elnagyoltan, de pontosan követi az eseménytörténetet. Calais szerepe és elfoglalása (1347), a Poitiers melletti csata (1356) leírása, az Agincourt melletti ütközet (1415) bemutatása tulajdonképpen mind-mind megfelel a valóságnak. Magunk abban sem találunk semmi sértőt a franciákra nézve, hogy Jeanne D’Arc nem név szerint szerepel, és halálának körülményeit Chalkokondylés nyilvánvalóan nem ismeri. Annak azonban szemlátomást tudatában van, hogy a Franciaország területéről kiszorított angolok Calais-t még hoszszú időn át megtartották hídfőállásnak. A százéves háborúról szóló részben található az a mondat is, ami alapján Ducellier úffent meggyőződik Chalkokondylés franciaellenes szemléletéről (II, 36): ${ }^{19}$ „Némelyek viszont úgy tartják, hogy a franciák számára nem megengedett elfutni az ütközetből, inkább fegyverrel a kezükben esnek el a csatamezőn. A franciák éppen emiatt gondolják, hogy bátorságban túltesznek a többieken, és ők a legkiválóbbak valamennyi nép közül."20 Öszintén megvallva a mondat többszöri olvasása után sem látjuk világosan, mi lehet itt a franciákat sértő tartalmi elem, ${ }^{21}$ hacsak Ducellier nem arra gondolt, hogy a szerző szerint a franciák nem hajlíthatatlan jellemükből adódóan, hanem valamiféle sajátos hiúságból vállalják a halált, csakis azért, hogy később a kedvező megítélésük érdekében hivatkozni tudjanak önfeláldozásukra. A görög szöveg érzésünk szerint nem ezt akarja mondani, magunk sokkal inkább a spártaiak hősies viselkedését megidéző magatartás dicséretét véljük felfedezni a sorokban.

Ugyanakkor máshol tagadhatatlanul kritikus a hangvétel, a francia nép túlzott öntudatára, gőgjére vonatkozó szórványos megjegyzések mögött azonban nem Chalkokondylés személyes véleményének tendenciózus elfogultságát feltételezzük, hanem a francia népre vonatkozó nemzetkarakterológiai sztereotípiák közvetett, forrásokon keresztül történő átvételét. ${ }^{22} \mathrm{~A}$ források pontos meghatározása jelen ismereteink alapján lehetetlen, de nem kell sokáig keresgélnünk a kora középkor latin nyelvü irodalmi hagyományában, hogy hasonlóan dehonesztáló kijelentésekre akadjunk, ${ }^{23}$ és akkor még nem is beszéltünk az esetleges szóbeli forrásokról, melyek végképp feltárhatatlanok.

${ }^{19}$ Ducellier: i. m. 1973 (5. jegyz.) 444: „Et c'est l'occasion pour Chalkokondylis de lancer un nouveau trait contre la présomption insensées des Francais."

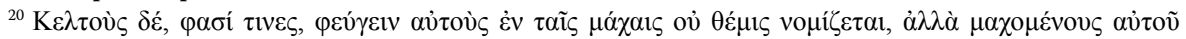

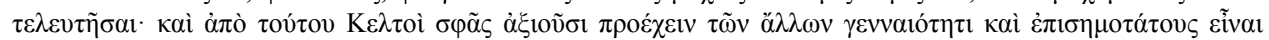
$\dot{\alpha} \pi \alpha ́ v \tau \omega v$.

${ }^{21}$ A görög mondat franciául Ducellier fordításában: „Il n’est pas permis pour les Francais fuir dans les batailles: ils doivent mourir sur le lieu du combat, maxime dont ils tirent grand orgueil pour se considérer comme le plus courageux du monde."

${ }^{22}$ A nemzetkarakterológiai kutatások általános áttekintése további bőséges szakirodalommal: C. Weeda: Ethnic Identification and Stereotypes in Western Europe, circa 1100-1300. History Compass 12/7 (2014) $586-606$.

${ }^{23}$ Lásd például Salvianus: De gubernatione Dei 4, 67: „gens (...) Francorum infidelis”; 7, 64: „Franci mendaces”; stb. A példák száma jócskán gyarapítható. Vö. P. Meyvaert: „Rainaldus est malus scriptor Francigenus" - Voicing National Antipathy in the Middle Ages. Speculum 66 (1991) 743-763. 
Könnyen meglehet, hogy Chalkokondylést az az anconai Kyriacus (Ciriaco d'Ancona, Ciriaco de’ Pizzicolli) tájékoztatta a nyugat-európai történelmi eseményekről, aki fentebb már idézett naplójának 1447 nyarán kelt bejegyzései alapján a peloponnésosi Mystrában személyesen is eltöltött néhány napot szerzőnk társaságában, de azt sem zárhatjuk ki, hogy egy másik Chalkokondylés, a Padovában, Firenzében, majd Milánóban görögtanárként szédületes karriert befutó rokon, Démétrios is szerepelt az informátorok között.

Az egész kelta-exkurzus szövegére jellemző, hogy ha tüzetesebb vizsgálat alá vetjük a beszámoló első olvasásra érthetetlennek tűnő vagy megmosolyogtató állításait, valamilyen igazságtartalmat, hivatkozási alapot mindig találunk a kijelentések mögött. Nézzünk néhány példát! Ami a „Franciaország kapujaként számon tartott Genova” mondatot illeti, ${ }^{24}$ Chalkokondylésnek a Földközi-tenger tengeri útvonalait - így a Franciaországba irányuló és onnan kiinduló hajóforgalmat is - ellenőrzése alatt tartó városról nyilvánvalóan a latin ianua (kapu, ajtó) > Genova etimológia jutott eszébe ${ }^{25}$ Hogy nagyon is tisztában volt Genova és Franciaország valós elhelyezkedésével, világosan kiderül a mű későbbi részéből, a „Genova-exkurzusból”. ${ }^{26}$ A Roland halálára vonatkozó állítást („egy ostrom során szomjan halt” ${ }^{27}$ talán meghökkenve hallja, aki a történet másik változatát ismeri. Ugyanakkor az irodalmi hagyományban akad olyan variáns is, ahol Roland nem a roncesvalles-i csatában hal hősi halált, hanem a Pireneusokon való átkelés után végez vele az éhség és a szomjúság, ${ }^{28}$ ahogy erre a mai angol köznyelvben már-már szállóigeként élő „to die like Roland” kifejezés is utal. A százéves háború történetét röviden összegző szakaszokból magyarázatra szorul az a kijelentés, hogy az angolok győzelmével végződő egyik összecsapást „a Bánat mezeje nevű helyen vívták meg”. ${ }^{29}$ Itt az 1415. október 25-én Azincourt/Agincourt mellett zajlott ütközetről van szó. Alighanem az történt, hogy a szerző - vagy inkább forrása - a helynevet félreértésből a

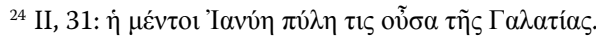

${ }^{25}$ Chalkokondylés tudott latinul (és így feltehetően olaszul is). Vö. az anconai Kyriacus beszámolóját: Bodnar: i. m. (15. jegyz.): „Et utique regia ipsa in aula mihi obviam occurrentem vidi iuvenem ingenuum $\mathrm{Ni}$ colaum X $\alpha \lambda_{\kappa о к \alpha} \alpha \delta \dot{\eta} \lambda \eta \nu$ Athenisensem, Georgi amicissimi nostri et viri doctissimi filium nequidem degenerem, quin et egregie Latinis atque Graecis litteris eruditum."

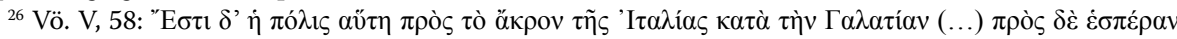

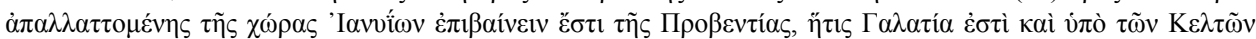

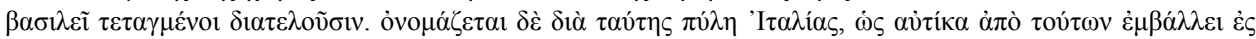
$\Gamma \alpha \lambda \alpha \tau i ́ \alpha v$. „Ez a város Itália szélén található, a Franciaország felé eső részen. (...) Ha nyugati irányban elhagyjuk Genova területét, átlépünk Provence-ba, ami Franciaország része, lakói a francia király alattvalói. Amiatt hívják Itália kapujának, mert rögtön utána Franciaországba jut az ember."

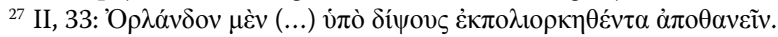

${ }^{28}$ Jean La Bruyère-Champier, I. Ferenc, majd II. Henrik francia királyok orvosa így ír a De re cibaria című művében $(16,5)$ : „Nonnulli qui de Gallicis rebus historias conscripserunt, non dubitarunt posteris significare Rolandum Caroli magni illius sororis filium, virum certe bellica gloria omnique fortitudine nobilissimum post ingentem Hispanorum caedem prope Pyrenaei saltus iuga, ubi insidiae ab hoste collocatae fuerint, siti miserrime extinctum. Inde nostri intolerabili siti et immiti volentes significare se torqueri, facete aiunt, Rolandi morte se perire."

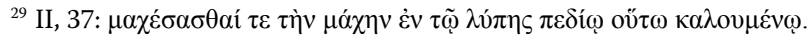


nem létező Chagrincourt névvel kötötte össze (a francia chagrin jelentése: 'szomorúság', 'bánat,' 'fájdalom'). ${ }^{30}$

Summa summarum: magunk nem érzékeltünk a szövegben sem a bizánciakra állítólagosan jellemző alapvető földrajzi tájékozatlanságot, sem vallási alapú nyugatellenességet, $\mathrm{s}$ végképp nem találtuk nyomát a korábbi frank hódítás során elszenvedett sérelmeknek. A „franciaellenes szemlélet” helyett pedig a szemelvények sokkal jellemzőbb vonásának tekintjük a szerző törekvését a hérodotosi historiográfiai hagyomány felélesztésére, melynek módszereit és eszközeit, a tárgyilagosságra való törekvést, az anekdotikus elemek felhasználását, valamint az adatok lehetőség szerint pontos közlését Chalkokondylés is előszeretettel alkalmazza.

\author{
MÉszÁros TAMÁs \\ ELTE Eötvös Collegium \\ Byzantium Központ \\ tamas.m.meszaros@gmail.com
}

${ }^{30}$ Vö. W. Miller: The Last Athenian Historian. JHS 42 (1922) 46: „Under the name of »the plain of the grief « he evidently conceals the battle of Azincourt, which he had heard pronounced and mistook for Chagrincourt." Valószínűbbnek tartjuk, hogy Chalkokondylés ezúttal csak átvette és közölte a forrásától hallott etimológiát, mert francia nyelvtudása nem bizonyítható, kevéssé valószínű. 


\section{FÜGGELÉK}

„(30) A francia nép nagy, gazdag és ősi nép. Önmagukat sokra tartják, azt hiszik, hogy különbek a többi nyugati nemzetnél, s úgy gondolják, hogy őket illeti a vezető szerep és a római birodalom. Országukat kelet felől Lombardia, délről Ibéria, északról Németország, nyugatról pedig az óceán és a Brit-szigetek határolja. Területe az Alpoktól, mely Itálián túl található, egészen az óceánig és Németországig terjed, Itáliától az óceánig haladva nagyjából tizenhét napnyi út, Ibériától Németországig pedig mintegy tizenkilenc napnyi út. Párizs városa, a francia király székhelye kiemelkedik jelentőségének és gazdagságának köszönhetően. Franciaországban a városok száma nem kevés, irányításuk azonban személyesen a király kezében van, bár vannak tartományok is, valamint főrak, akik jelentős befolyással rendelkeznek és rendkívül gazdagok, de ők is a király alattvalói, s rendszeresen felkeresik a palotájában. (31) Burgundia urának birtoka kiterjedt és jelentős, számos egyéb település mellett övé Bruges városa, Sluis a tenger partján, valamint Gent gazdag és nagy városa a szárazföld belsejében. Bruges kikötőváros, az óceán partján fekszik az Angliának nevezett Brit-szigettel szemben. Bruges kikötőjébe mind a mi tengerünkről, mind Németország, Spanyolország, Anglia, Dánia és a többi nagyhatalom tengerparti városaiból érkeznek hajók. A város maga százötven stadion távolságra található Angliától, a térség pedig a Flandria nevet viseli. Burgundia urai említésre méltó tetteket vittek végbe a franciák földjén hol a francia király, hol pedig a britek ellen. Aztán következik Britannia szárazföldi része, a király területéhez tartozó föld közvetlen szomszédságában. Rajtuk kívül (...), ${ }^{31}$ ezen földek szomszédságában pedig Szavoja urának birtoka, egy nagy és különösen szép tartomány, mely Lombardiáig tart. Ami pedig Franciaország tengerparti részét illeti, a kutatásaim szerint a következő a helyzet. A Franciaország kapujaként számon tartott Genova fennhatósága alatt áll a Provence vidékéig terjedő terület, míg Provence maga a francia uralkodócsaládból származó René király birtoka. Provence székhelye Nizza, de városai közé tartozik Avignon is, ahol a földkerekség egyik leghosszabb hídja található, ami egészen Beaucaire vidékére vezet. ${ }^{32}$ Dióhéjban ez Franciaország. (32) Úgy tartják, hogy a francia ősi nép, és hősies viselkedést tanúsított az észak-afrikai barbárokkal szemben, amikor még a rómaiak uralkodói és császárai a francia királyok voltak. Ezen királyok közül leginkább Károly jeleskedett az észak-afrikaiak elleni háborúban. A küzdelemben unokaöccse, Orlando segítette, egy vakmerő és katonai kérdésekben kiemelkedően tehetséges férfi, valamint Rinaldo, Oliviero és más helyi főrak is részt vettek a háborúban, akiket paladinoknak neveznek. A harc többfelé folyt, Károly először Franciaország területén, majd aztán Ibériában ara-

\footnotetext{
${ }^{31}$ A szöveg itt hiányos.

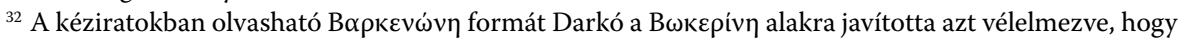

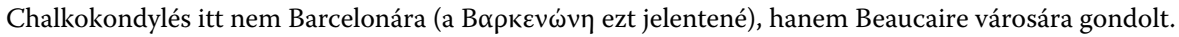


tott fényes győzelmet, megfutamítva az ellenséget. Dicsőségüket mind a mai napig zengi mindenki Itália-, Ibéria- és Franciaország-szerte. Az észak-afrikaiak ugyanis átkeltek Héraklés-oszlopain, és fokozatosan előrehaladva megszállták Ibériát, aztán egészen Aragóniáig nyomulva meghódították Navarra és Portugália földjét, és miután a térséget uralmuk alá hajtották, betörtek Franciaországba. (33) Ezekkel az észak-afrikaiakkal viseltek tehát háborút Károly és társai, a harc során alaposan kitettek magukért, dicsőséges tetteket hajtottak végre, végül a keltibérek és a franciák földjéről elűzték az ellenséget Granadába, egy hegy lábánál fekvő bevehetetlen városba az óceán partjánál. A franciák lassacskán elérték a tengerszoros környékét, megszállták Ibéria jelentős részét, berendezkedtek, és közösen hadba indulva próbálták visszahódítani a városokat. Az elfoglalt tartományokat, vagyis Kasztíliát, Navarrát és Aragóniát átadták saját szövetségeseiknek, a barbárok támadásától fenyegetett társaikat felszabadították az ostrom alól, a földet pedig újból felosztották egymás között, s ki-ki az őt megillető részt elnyerve telepedett le. Olyan sikeresen vívták a háborút, hogy mind a mai napig dalt zengenek hősies viselkedésükről. Orlandótól, a sereg parancsnokától, aki egy ostrom során szomjan halt, Rinaldo vette át a háború vezetését, majd az ibériai királyoknak adta át a feladatot, ők pedig még ma is folytatják a háborút, össze-össze szoktak csapni az észak-afrikaiakkal. Ez az észak-afrikai nép arab nyelven beszél, Mohamed szokásait és vallását gyakorolja, ruházata részben arab, részben viszont ibériai jellegü. (34) Ami a franciákat illeti, a háborúban játszott szerepük miatt szörnyen büszkék a történtekre, azt képzelik, hogy előkelőségük folytán különbek valamennyi nyugati nemzetnél. A franciák életmódja az itáliai életvitelnél elpuhultabb, öltözködésük hasonlatos amazokéhoz, nyelvük viszont különbözik az itáliai nyelvtől, de nem annyira, hogy az itáliaiakéhoz képest az övék más nyelvnek tűnjön. Elvárják, hogy ahol csak megjelennek, övék legyen az első hely a nyugati népek között. (35) A fennhéjázásuk mindenesetre alábbhagyott a Britanniában élő angolok jóvoltából, miután ez a nép hosszas harcokat követően leigázta az országukat és lakóit, megkaparintotta magának a vezető szerepet, és seregével ostromolni kezdte fővárosukat, Párizst. A viszálykodásuk oka állítólag a következő volt. Van egy Calais nevü város Franciaország partvidéki szakaszán, az óceán mellett. Nem különösebben ismert, mégis fontos város, mert innen indul a Franciaországból Britanniába vezető tengeri út, és Calais az átkelés szempontjából kedvező fekvése révén alkalmas támaszpontként szolgál, ha az ember abból az irányból készül betörni Franciaországba. Ezt a várost a brit király a helybéliek árulásának köszönhetően rajtaütéssel elfoglalta, megszállta és fennhatósága alá vonta. Mikor a francia király megpróbálta visszakérni, közölte, hogy nem hajlandó visszaadni, majd a szigetről csapatokat küldött a városba. A francia király ennek ellenére megtámadta és jó ideig ostromolta a várost, de aztán, mivel az ostrom semmilyen eredményt nem hozott, visszaparancsolta a seregét és hazament. (36) Később a brit király jelentősebb sereget gyűjtött, katonái átkeltek Franciaországba és fosztogatni kezdték a vidéket. Egyszer összecsaptak egy nagyobb francia csapattal, és a harcban leöldösték a franciák többségét. A következőképpen történt mindez. Mikor egy alkalommal az angolok a fosztogatással voltak elfoglalva, és éppen hazafelé tartottak a zsákmánnyal, mielőtt biztonságban megérkeztek volna Calaisbe, a 
franciák rajtuk ütöttek, és bekerítették őket egy dombon. A britek kutyaszorítóba kerültek, mert nem tudták, hogy merre meneküljenek, úgyhogy megüzenték, hogy átadják a zsákmányt és fegyvereiket, amennyiben biztosítják számukra a szabad elvonulást. A franciák viszont közölték, hogy nem engedik el őket, míg meg nem fizetnek a földek fosztogatása során a franciák ellen elkövetett bűneikért. A britek ebből megértették, hogy ütött az utolsó órájuk, így aztán nekimentek a franciáknak, és bár maroknyian szálltak szembe a túlerővel, kitettek magukért, megfutamították az ellenséget, üldözőbe vették a menekülőket, és ott ölték őket, ahol érték. Némelyek viszont úgy tartják, hogy a franciáknak nem szokásuk elfutni az ütközetből, inkább fegyverrel a kezükben esnek el a csatamezőn. A franciák éppen emiatt gondolják, hogy bátorságban túltesznek a többieken, és ők a legkiválóbbak valamennyi nép közül. (37) A történtek után mindenesetre a britek már kisebb aggodalommal indultak a francia városok ostromára, lépésról lépésre haladtak elöre, és a Bánat mezeje nevű helyen vívták meg az ütközetet az ellenséggel. Az egyenlő erőkkel felsorakozó angolok ott töltötték az összecsapást megelőző éjszakát, aztán másnap a csatában öldösni kezdték a franciákat. Mivel azok rendezetlenül, összevissza harcoltak, és ki-ki ment a maga feje után, oda is vesztek. Miután a britek jóformán az egész országot meghódították, a királyi udvar ellen indultak, egyenesen Párizs városába. Úgy tűnt, hogy a franciák helyzete végképp megpecsételődött. Mikor a franciák már csak az isteni csodában bízhattak, mert ha súlyos csapás fenyeget, akkor az ember általában leginkább az istenbe vetett hitére szokott hagyatkozni, megjelent köztük egy nő, szépségre sem utolsó, aki azt állította, hogy az isten beszélget vele. A franciák élére állt, ők pedig követték, és hallgattak a szavára. A nő odavezette őket, ahová elmondása szerint az isten mutatta, és egyesített csapataikkal a britek ellen vonultak, hogy újból megütközzenek velük. Ott töltötték az éjszakát, másnap pedig a régi bátorsággal mentek a csatába a nő vezetésével, a harcban megfutamították az ellenséget, és üldözőbe vették a menekülőket. Később a nő meghalt ebben a háborúban, a franciák azonban összeszedték magukat, és új erőre kapva folytatták a harcot a britekkel, visszafoglalták városaikat, és kitartóan védelmezték országukat, miközben Britanniából folyamatosan keltek át Franciaországba a létszámban és erőben jelentős csapatok. Az összecsapásban a franciák a britek fölé kerekedtek, míg végül visszaszorították Calaisba, és kiűzték földjükről az ellenséget."

A cikk a Creative Commons Attribution 4.0 International License (https://creativecommons.org/ licenses/by/4.0) feltételei szerint publikált Open Access közlemény, melynek szellemében a cikk bármilyen médiumban szabadon felhasználható, megosztható és újraközölhető, feltéve, hogy az eredeti szerző és a közlés helye, illetve a CC License linkje és az esetlegesen végrehajtott módosítások feltüntetésre kerülnek. (SID_1) 